\title{
SISTEM INFORMASI ASET (SIMaset) BARANG DAN DOKUMEN BERBASIS WEB
}

\author{
Miftahul Jannah', ${ }^{1}$ Suhartono², Udin Sidik Sidin ${ }^{3}$ \\ 1,2,3 Jurusan Teknik Informatika dan Komputer \\ Fakultas Teknik Universitas Negeri Makassar \\ Jl. A.P. Pettarani, Makassar, Sulawesi Selatan. 90000 \\ ${ }^{1}$ E-mail: annaahawa@gmail.com
}

\begin{abstract}
Abstrak: Manajemen aset berbasis web perlu dikembangkan untuk mempermudah pendataan barang dan dokumen di perguruan tinggi karena berkaitan dengan keamanan data. Perlu dikembangkan sistem informasi online yang akurat dan mudah. Penelitian ini berupa penelitian pengembangan perangkat lunak yang bertujuan untuk mengembangkan aplikasi SIMAset berbasis web dan menguji kualitas aplikasi berdasarkan standar kualitas ISO25010 yang terdiri dari aspek functionality, reliability, portability dan usability. Metode yang digunakan adalah R\&D. Model pengembangan yang digunakan dalam penelitian ini adalah prototipe. Berdasarkan hasil penelitian, dihasilkan aplikasi berbasis web yang dapat digunakan dalam pengelolaan inventaris perguruan tinggi secara online. Hasil uji validasi dari tim ahli menunjukkan bahwa SIMaset yang dikembangkan sangat cocok digunakan sebagai sistem informasi untuk pengelolaan dokumen barang dan inventaris. Untuk penelitian selanjutnya, sistem ini akan mengembangkan menu-menu tertentu yang disesuaikan dengan kebutuhan pengarsipan aset dan dokumen.
\end{abstract}

Kata Kunci: aset, informasi, prototipe, sistem, web

\section{PENDAHULUAN}

$\mathrm{K}$

emajuan yang sangat pesat di bidang teknologi informasi, terutama komputer dan internet dalam hal pengelolaan data tentu akan sangat membantu meringankan pekerjaan yang selama ini dilakukan secara manual oleh pengguna baik secara individu, organisasi atau lembaga maupun kelompok. Manfaat suatu informasi mempunyai dampak yang cukup besar terhadap perkembangan lembaga itu sendiri (Indrayani, 2011). Informasi yang berkualitas atau bernilai tinggi hanya bisa dihasilkan dari sebuah sistem informasi yang juga berkualitas (Lipursari, 2013). Ditambah lagi dengan hadirnya teknologi online seperti layan internet yang semakin memudahkan penggunaannya dalam mengakses segala macam informasi dari data yang disajikan.

Seiring dengan perkembangan teknologi yang begitu cepat, seyogyanya setiap instansi memanfaatkan teknologi tersebut termasuk di perguruan tinggi. Perguruan tinggi harus merancang sistem pelayanan dan pengarsipan dalam memajukan kinerja untuk menciptakan good governance dalam pelayanan pendidikan di perguruan tinggi. Sejauh ini, setiap universitas telah mengikuti perkembangan IPTEK, hal ini ditandai dengan adanya fasilitas komputer serta internet di kampus yang dapat menunjang kinerja pegawai (Nugraha et al., 2021). Meskipun fasilitas komputer dan internet sudah ada namun masih banyak pengelolaan administrasi yang masih dilakukan secara manual 
(Heryanto et al., 2014). Hasil observasi lapangan menunjukkan pengelolaan administrasi masih banyak yang dilakukkan secara manual dan tidak tercatat dengan baik seperti inventaris barang yang hanya dicatat dan ditandai dengan cat, arsip-arsip yang hanya dibukukan, dokumen perpustakaan yang masih sistem komputer lokal, serta persoalan barang yang sering tercecer karena datanya tidak diketahui (Sidiq \& Kurniawati, 2019).

Semua keterangan mengenai barang inventaris dicatat dalam suatu buku, sehingga untuk catatan barang-barang di tahun-tahun sebelumnya sulit ditemukan karena pengelolaan yang digunakan masih sangat sederhana (Jimmy, 2019). Buku inventaris disimpan dalam lemari yang digunakan sebagai tempat penyimpanan data-data atau sering disebut sebagai tempat pengarsipan yang sewaktu-waktu akan diambil apabila diperlukan (Werb \& Lanzl, 1998). Akibatnya, apabila ada pihak yang membutuhkan laporan inventaris barang sulit untuk mencari keterangan dimana dan apa saja barang yang dibutuhkan (Ariska \& Jazman 2016).

Permasalahan yang sering terjadi pada pengelolaan data inventaris barang secara konvensional adalah masalah keamanan data. Kesulitan admin dalam proses pencarian data barang dan pelaporan data inventaris barang yang membutuhkan waktu yang cukup lama yang mengakibatkan data yang diperoleh tidak akurat dan memakan waktu yang lama (Hilbert, M., 2016). Hal ini disebabkan karena belum adanya sistem pengelolaan dan penyimpanan data khususnya pada pengelolaan dan penyimpanan data inventaris barang. Oleh karena itu, untuk mengatasi permasalahan yang ada dibutuhkan sebuah sistem basis data yang bertujuan untuk menyimpan data yang diproses sistem, agar keamanan data inventaris barang terjaga, mempermudah admin untuk menyimpan data dan mengelola data serta mempermudah pihak yang membutuhkan dalam menerima laporan data inventaris barang (Azhar, 2011).

Pengelolaan inventaris barang secara manual dianggap tidak mampu lagi mengikuti laju kebutuhan informasi yang semakin cepat dan efisien. Pendataan inventaris barang membutuhkan pengelolaan yang cepat dan akurat (Saryani, 2019). Pengelolaan inventaris barang harus ditangani secra profesional karena menyangkut aset kampus yang harus diolah secara cepat dan akurat (Karim, 2018). Sistem informasi secara konvensional dapat diatasi dengan merancang sistem informasi inventaris barang berbasis web. Sistem yang dianggap lebih efektif karena mudah untuk dijalankan dan dapat diakses kapanpun, dimanapun, karena semua aplikasi cukup dijalankan dengan browser, sehingga pencarian data barang dapat dilakukan secara cepat, tepat dan akurat (Junglas, 2008). Selain itu, pendataan inventaris barang dapat disimpan dengan jumlah banyak dalam suatu basis data dan lebih rapi, tidak takut kehilangan data karena virus atau komputer yang diinstal ulang.

Ada beberpa penelitian serupa yang telah dilakukan oleh para ahli tentang aplikasi sistem inventaris dan kearsipan. Sholikhin \& Riasti (2013) telah merancang sistem informasi inventrais sekolah di kab Rembang. Hasil penelitiannya menyimpulkan bahwa dengan sistem informasi berbasis web akan memudahkan koordinasi inventaris sekolah dan efesiensi kerja. Penelitian selanjutnya adalah Agusvianto (2017) dengan fokus pada sistem informasi inventori pada gudang. Hasil penelitian ini menjelaskan bahwa dengan laporan berbasis web, kantor pusat dapat mengontrol dan melihat laporan dari gudang dengan tepat sasaran dan akurat. Selanjutnya Sari \& Nuari (2017) merancang sistem informasi barang dan jasa berbasis web dengan metode fast. Hasil rancangannya menemukan bahwa rancang bangun sistem informasi persediaan barang berbasis website menggunakan metode pengembangan sistem yaitu FAST (Framework 
for the Application System Thinking) terdiri dari fase-fase scope definition, problem analysis, requirements analysis, logical design dan physical design, dengan demikian sangat membantu dalam pengarsipan. Peneliti selanjutny adalah Pranoto \& Sediyono (2021) yang merancang inventaris barang berbasis web. Hasil penelitiannya menunjukkan implementasi sistem yang dihasilkan dari penelitian adalah fitur-fitur sebagai berikut: data pengguna, semua data barang yang dimiliki desa, data barang masuk, data barang keluar, menghindari perhitungan fisik, laporan mutasi aset, dan laporan barang, serta pembuatan barang laporan persediaan dapat dengan mudah dilakukan. Dengan adanya website sistem informasi inventarisasi berbasis web pada kantor Desa Kusik Batu Lapu Kalimantan Barat dapat meningkatkan kinerja aparat desa dalam mengelola data barang.

Berdasarkan hasil penelitian terdahulu dapat ditarik kesimpulan bahwa sistem web sangat membantu dalam pengelolaan inventaris aset pada instansi. Walaupun telah banyak penelitian serupa namun belum ada yang spesifik pada penanganan inventaris dan kearsipan di perguruan tinggi yang lebih kompleks dan belum memenuhi standar kualitas perangkat lunak ISO 25010. Tujuan dari penelitian ini adalah mengembangkan sistem informasi inventaris pada perguruan tinggi agar dapat membantu pengelolaan barang dan dokumen berbasis web.

\section{METODE PENELITIAN}

Penelitian ini adalah penelitian pengembangan perangkat lunak, sistem ini dirancang dan dikembangkan menggunakan metode perancangan Research and Development (penelitian dan pengembangan) ( $\mathrm{R} \& \mathrm{D})$ dengan model pengembangan prototipe yang terdiri dari tahap tahap preliminari, tahap formatif, dan tahap evaluasi. Sebuah prototipe adalah bagian dari produk yang mengeskpresikan logika maupun fisik antarmuka eksternal yang ditampilkan. Konsumen potensial menggunakan prototipe dan menyediakan masukan untuk tim pengembang sebelum pengembangan skala besar dimulai. Melihat dan mempercayai menjadi hal yang diharapkan untuk dicapai dalam prototipe. Dengan menggunakan pendekatan ini, konsumen dan tim pengembang dapat mengklarifikasikan kebutuhan dan interpretasi mereka. Tahapan dalam model prototipe terdiri atas pengumpulan kebutuah sistem, membangun prototipe, evaluasi prototipe, mengodekan sistem, menguji, evaluasi sistem dan menggunakannya.

Rancangan database diagram konteks digunakan untuk menggambarkan sistem dan lingkungan luar yang saling berhubungan. Diagram konteks sebagai transformasi suatu sistem yang dapat mentransformasikan alur data input menjadi output. Diagram konteks usulan dapat dilihat pada Gambar 1. 


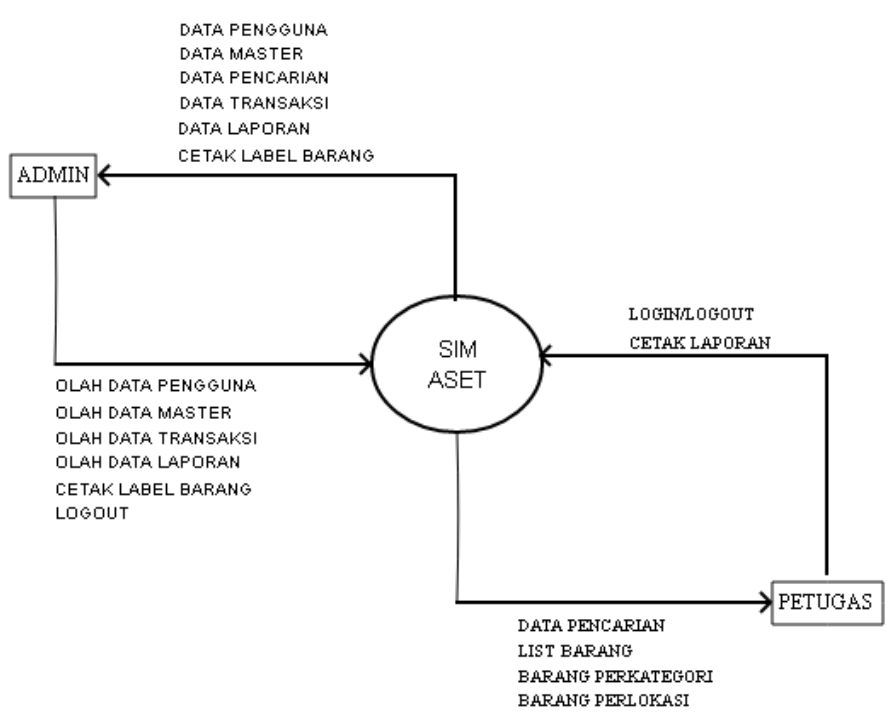

Gambar 1. Diagram konteks

Berdasarkan diagram konteks yang telah dirancang, dikembangkan data flow diagram (DFD) ke level 1 dan 2. Level 1 terdiri atas proses 1 dan 2, sedangkan level 2 yang terdiri atas proses 1 , proses 2 , dan proses 3 . Dari kedua level yang memiliki masing-masing proses, dikembangkan mnejadi entity relationship diagram (ERD) yang akan menghubungkan antar entritas sebagai dasar penentuan derajat relasinya (kardinalitas). Dalam proses tersebut, dirancang relasi tabel yang merupakan proses pengelompokan data elemen menjadi tabel-tabel yang menunjukkan entiti dan relasinya yang berfungsi untuk menentukan kunci yang mengakses data item atau merupakan database relation sedemikian rupa sehingga database tersebut menjadi modifikasi. Setelah proses tersebut adalah perancangan struktur database sebagai kebutuhan perancangan basis data untuk menentukan nama field, tipe field, panjang (length) dan keterangan field pada setiap database.

Kamus data dibutuhkan dalam pengembangan sistem informasi sebagai katalog data kebutuhan-kebutuhan informasi dari suatu sistem informasi. Dengan menggunakan kamus data, analisis sistem dapat mengidentifikasi data yang mengalir dalam sistem dengan lengkap. Kamus data berfungsi membantu pemakai dan analis sistem untuk mengartikan aplikasi secara detail sehingga pemakai dan analis sistem mempunyai dasar dan pengertian yang sama tentang masukan, keluaran, penyimpanan dan proses dalam sebuah sistem informasi. Selanjutnya pengembangan bahasa spesifikasi standar atau unified modelling language (UML) yang terdiri atas use case diagram, flowchart, dan activity diagram. Untuk memberikan gambaran tentang aplikasi yang akan dibangun, sehingga mudah pengimplementasiannya maka dirancang user interfaces bagian penghubung antara aplikasi sistem dengan pengguna.

Uji coba pengembangan sistem informasi inventaris barang dan dokumen berbasis web ini dilaksanakan di Jurusan Teknik Informatika dan Komputer, Universitas Negeri Makassar. Uji produk dinilai oleh tim pakar komputer untuk mengetahui kelayakan sistem informasi yang telah dikembangkan. 


\section{HASIL DAN PEMBAHASAN \\ Pengembangan Sistem Informasi}

Dalam tahap ini prototipe yang sudah disepakati diterjemahkan ke dalam bahasa pemrograman yang sesuai. Bahasa pemrograman web yang digunakan adalah Hypertext Preprocessor (PHP) dan menggunakan Software Sublime Text. Adapun sistem pengelolaan database menggunakan MYSQL. Beberapa script yang digunakan dalam pengembangan system dan pengelolaan database menggunakan MYSQL.

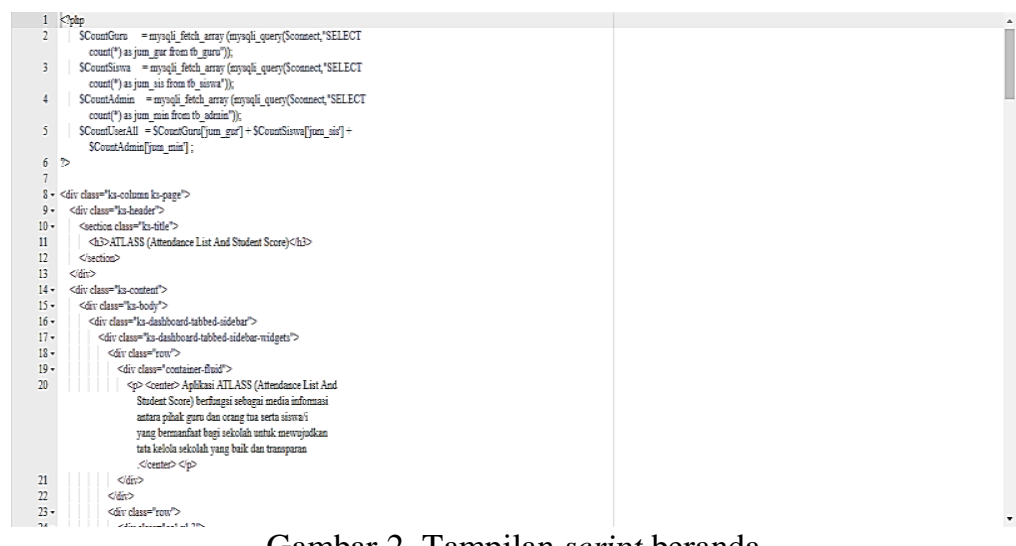

Gambar 2. Tampilan script beranda

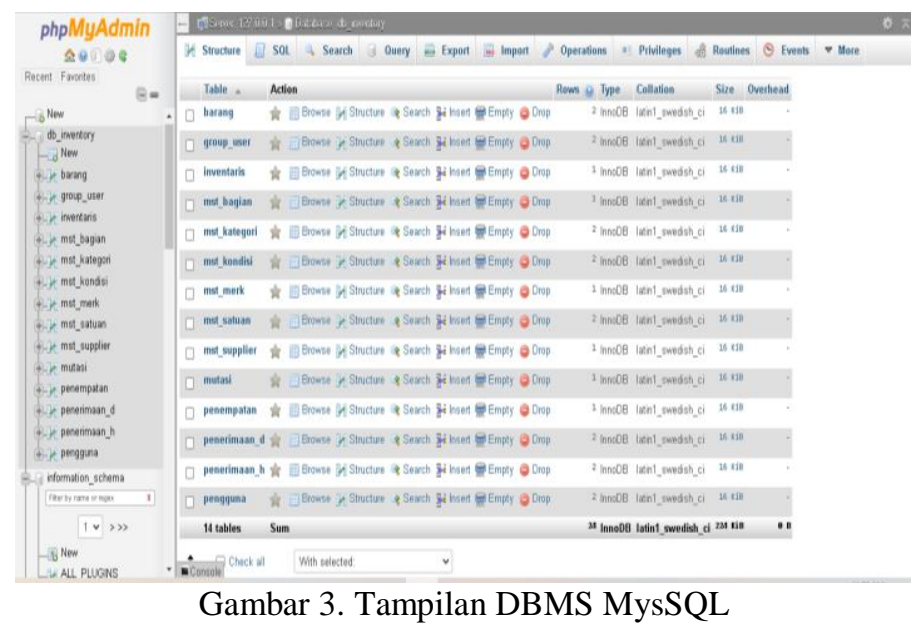

a. Interface admin

1) Form login

Form login merupakan halaman untuk validasi user dan password admin.

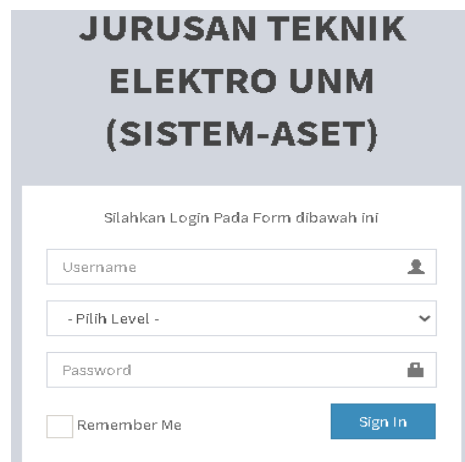

Gambar 4. Tampilan form login admin 


\section{2) Halaman home}

Halaman home merupakan halaman yang tampil pertama kali ketika admin membuka website.

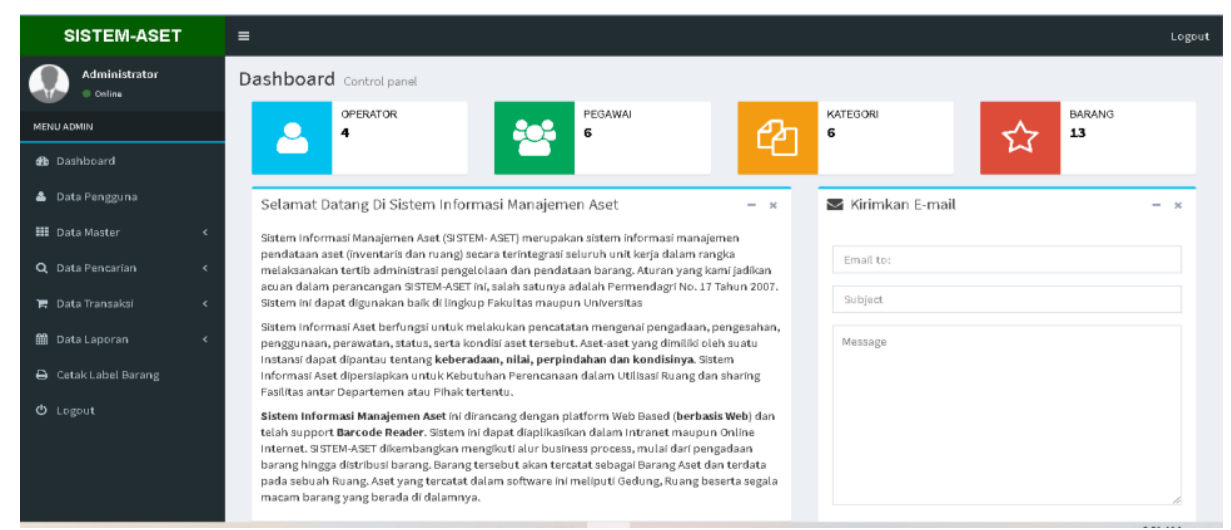

Gambar 5. Tampilan halaman home admin

3) Halaman data pengguna

Halaman data pengguna merupakan halaman untuk mengolah data pengguna.

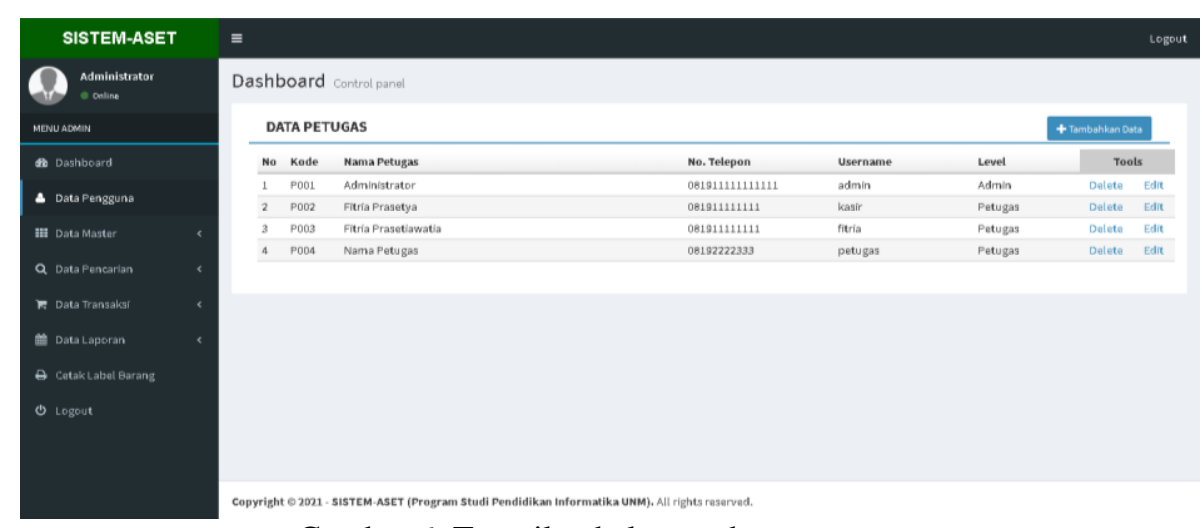

Gambar 6. Tampilan halaman data pengguna

\section{4) Halaman data master}

Halaman data master merupakan halaman untuk mengelola data yang terdiri dari data pegawai, data supplier, data departemen, data lokasi, data kategori dan data barang.

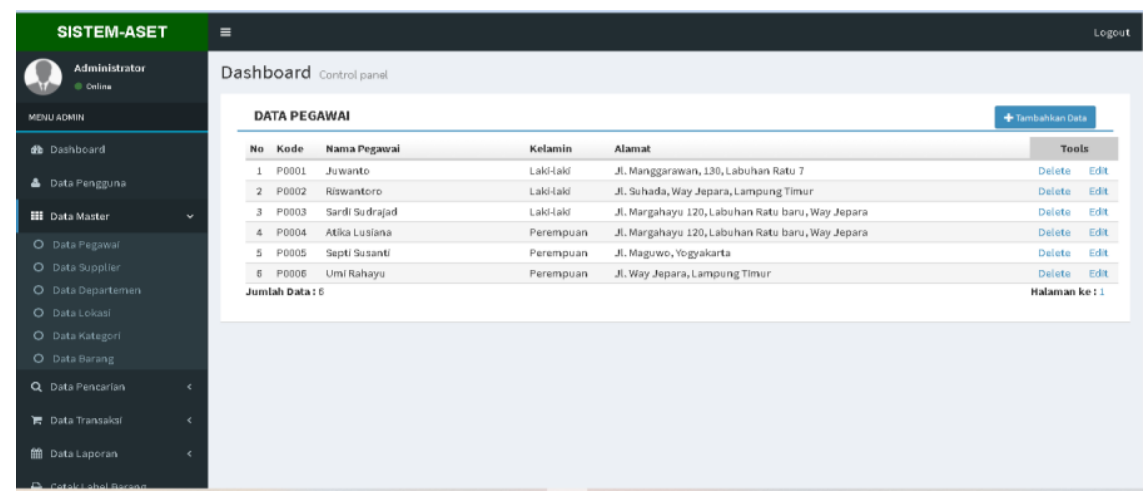

Gambar 7. Tampilan halaman data master 
5) Halaman data pencarian

Halaman data pencarian merupakan halaman untuk mencari barang terdiri dari pencarian barang 1 dan pencarian barang 2 .

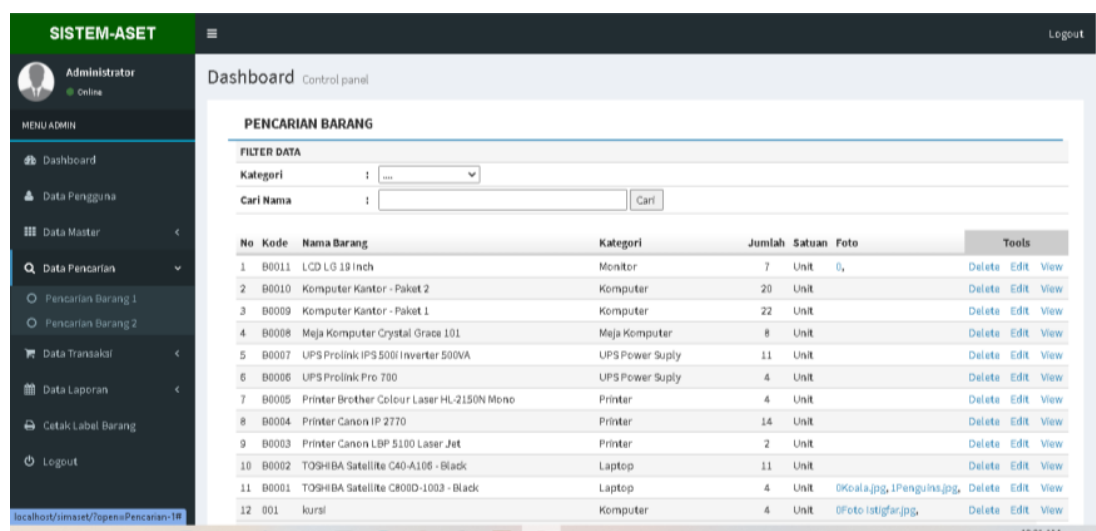

Gambar 8. Tampilan halaman data pencarian

6) Halaman data transaksi

Halaman data transaksi merupakan halaman untuk mengelola barang inventaris terdiri dari transaksi pengadaan, transaksi penempatan, transaksi mutasi dan transaksi peminjaman.

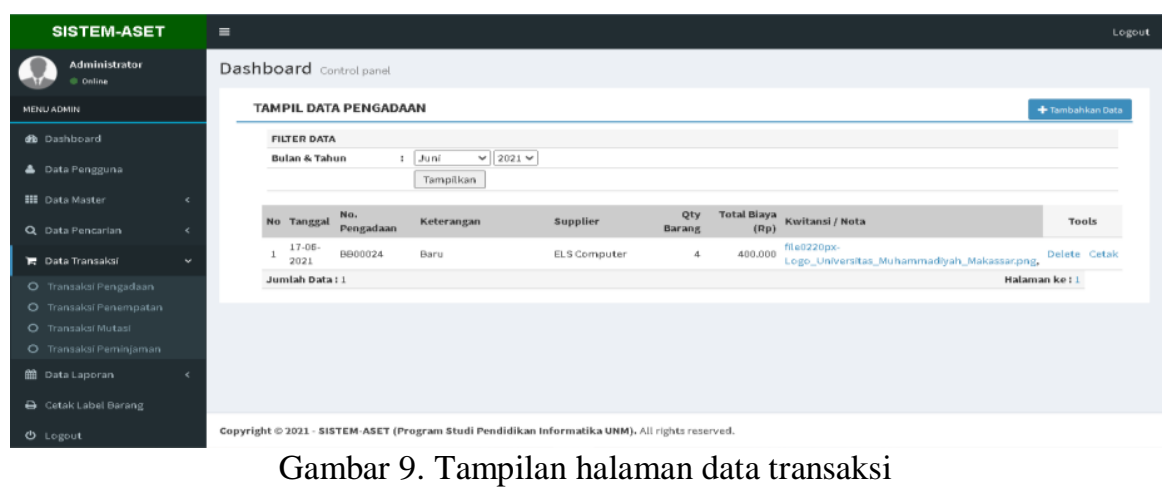

7) Halaman data laporan

Halaman data laporan merupakan halaman untuk mengelola data laporan terdiri dari data petugas, data supplier, data pegawai, data departemen, data lokasi, data kategori, laporan barang, laporan pengadaan, laporan penempatan dan laporan peminjaman.

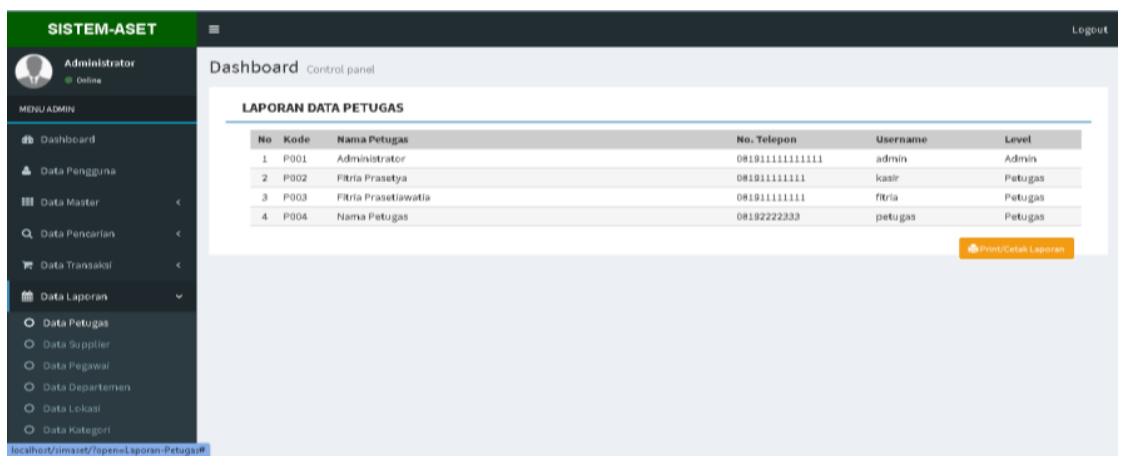

Gambar 10. Tampilan halaman data laporan 
8) Halaman cetak label barang

Halaman cetak label barang merupakan halaman untuk mencetak label barang.

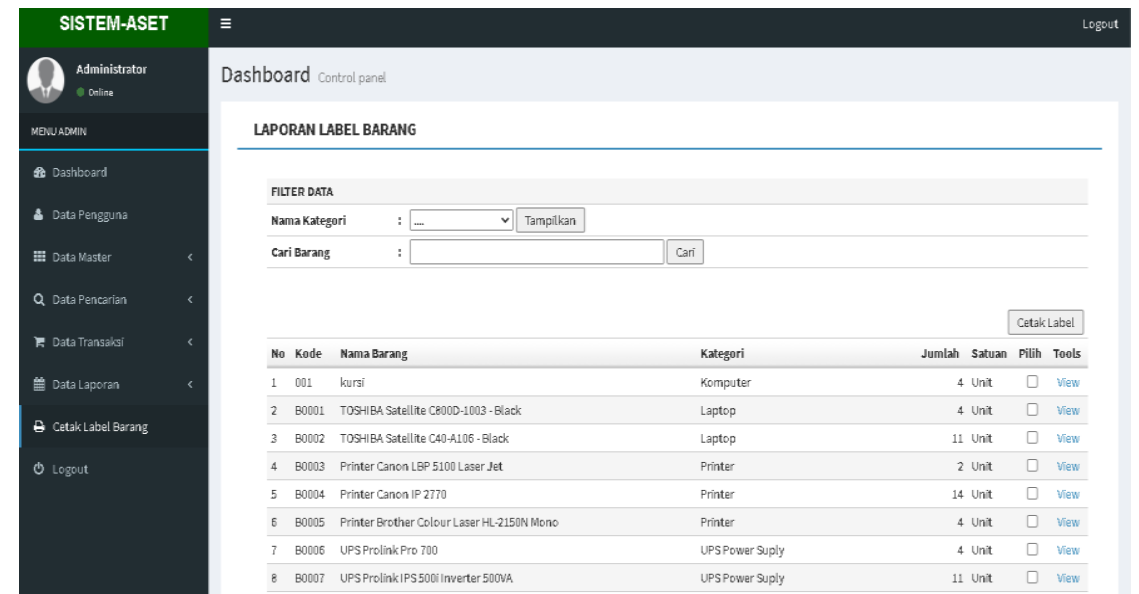

Gambar 11. Tampilan halaman cetak label barang

\section{b. Interfaces petugas}

1) Form login

Form login merupakan halaman untuk validasi user dan password petugas.

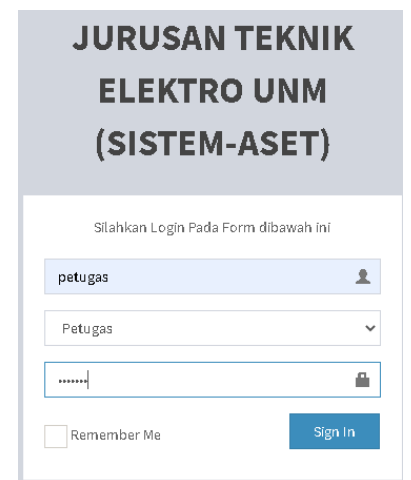

Gambar 12. Tampilan form login petugas

2) Halaman home petugas

Halaman home petugas merupakan halaman yang tampil pertama kali ketika petugas membuka website.

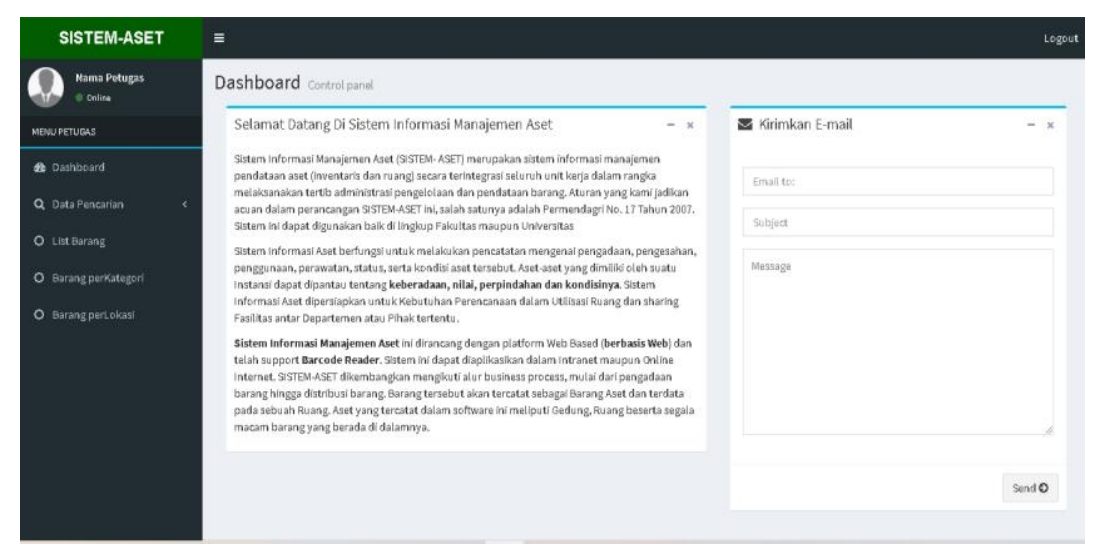

Gambar 13. Tampilan halaman home petugas 
3) Halaman data pencarian

Halaman data pencarian merupakan halaman untuk mencari barang.

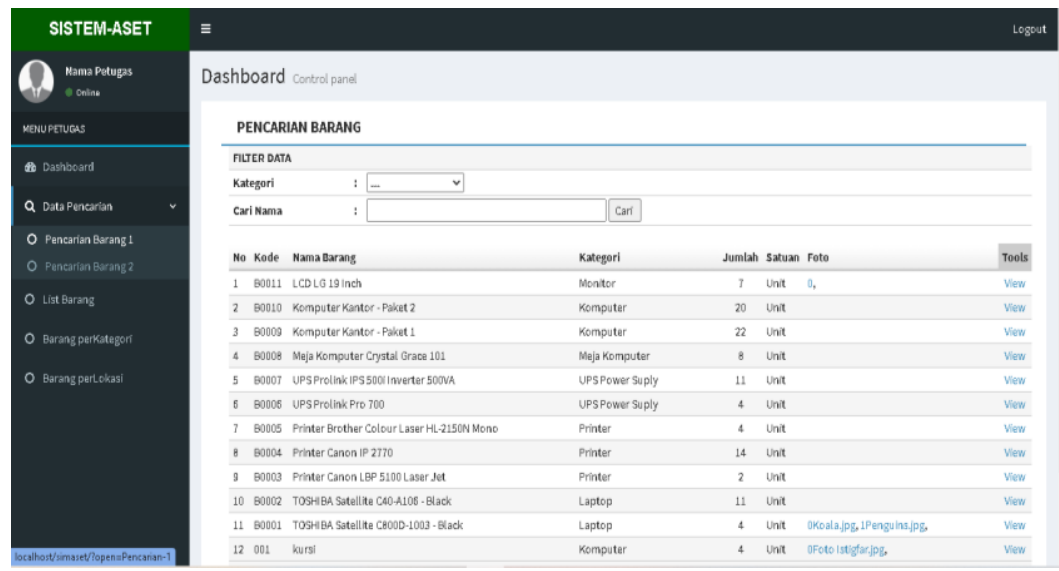

Gambar 14. Tampilan halaman data pencarian

4) Halaman list barang

Halaman list barang merupakan halaman untuk melihat dan mencari barang.

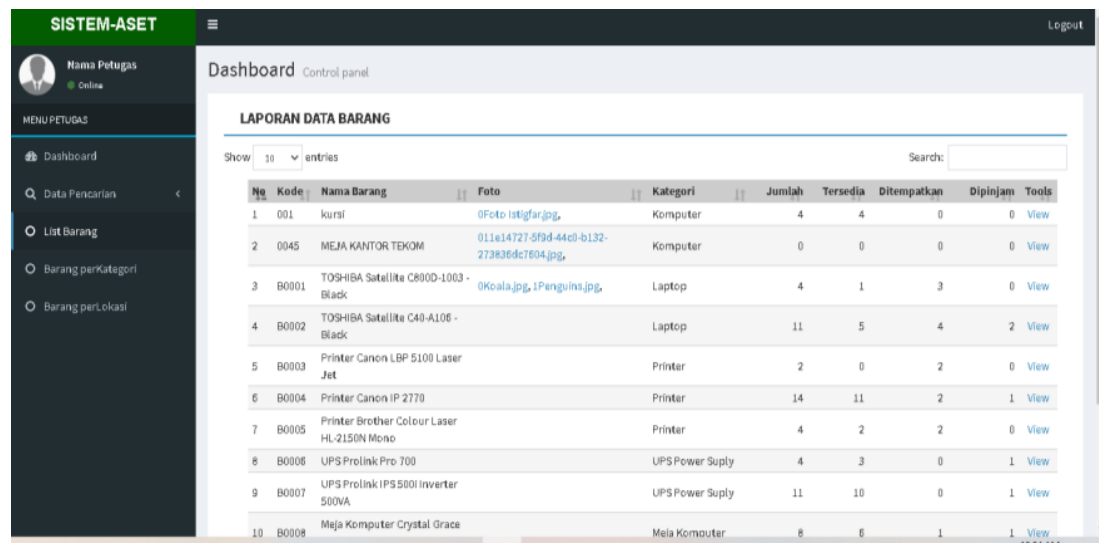

Gambar 15. Tampilan halaman list barang

5) Halaman barang perkategori

Halaman barang perkategori merupakan halaman untuk mencari barang sesuai dengan kategori barang.

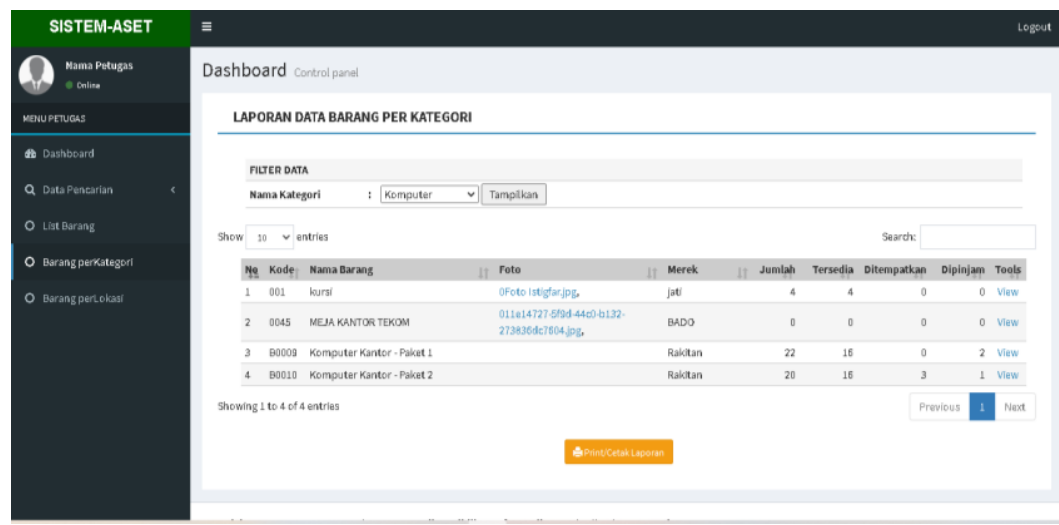

Gambar 16. Tampilan halaman barang perkategori 
6) Halaman barang perlokasi

Halaman barang perlokasi merupakan halaman untuk mencari barang sesuai dengan lokasi barang.

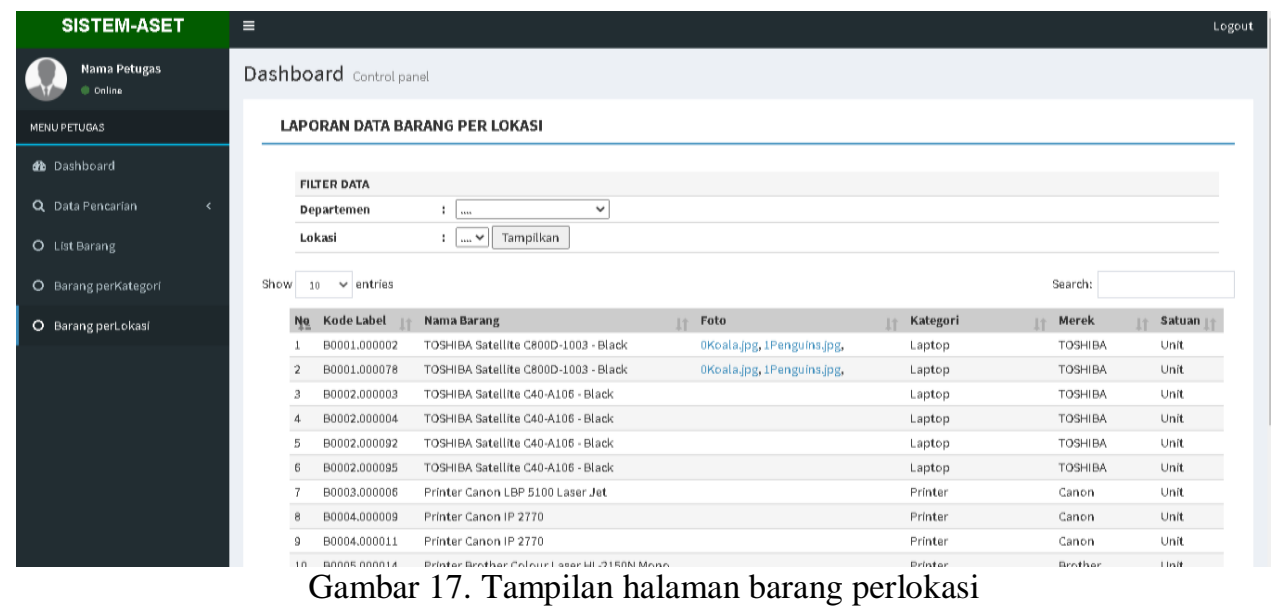

Setelah dilakukannya rangkaian penelitian, tahap akhir yang dilakukan adalah mengimplementasikan aplikasi SIMAset ini di JPTE Fakultas Teknik Universitas Negeri Makassar sehingga aplikasi ini dapat benar-benar digunakan dengan baik pada lingkungan yang sebenarnya serta diharapkan dapat menyelesaikan masalah-masalah yang telah dipaparkan sebelumnya.

\section{Uji Kelayakan}

Analisis data bertujuan menjelaskan hasil data uji coba. Kesimpulan hasil uji coba perlu ditunjukkan dalam bagian akhir dari butir ini. Penjelasan berikut ini yang digunakan sebagai dasar dalam melakukan revisi produk. Pada tahap ini dilakukan pengujian pada aplikasi yang telah dikembangkan berdasarkan standar kualitas perangkat lunak pada ISO 25010 yang terdiri dari aspek functionality, realibility dan portability. Untuk pengujian aspek usability dilakukan pada tahap selanjutnya yaitu evaluasi sistem. Selain aspek-aspek tersebut, pengembangan juga melakukan validitas instrumen yang akan digunakan pada uji coba lapangan.

1) Aspek functionality

Pengujian pada aspek funcionality menggunakan metode black box testing. Penilaian dilakukan berdasarkan instrument berupa test case. Instrumen pengujian funcionality berisi 88 test factor terkait fungsi-fungsi yang didesain dalam aplikasi yang dikembangkan. Instrumen functionality divalidasi oleh dua dosen selaku ahli media. Setiap fitur yang berjalan dengan baik maka dosen ahli akan memberikan checklist pada kolom "Ya" sedangkan bila fitur tidak berjalan dengan baik maka dosen ahli akan memberikan checklist pada kolom "Tidak".

Tabel 1. Rekapitulasi hasil penilaian functionality

\begin{tabular}{lccc}
\hline \multicolumn{1}{c}{ Validator } & Jumlah fitur yang didesain (P) & $\begin{array}{c}\text { Jumlah fitur yang berhasil } \\
\text { diuji (88) }\end{array}$ & Future completeness \\
\hline Ahli Media 1 & 88 & 88 & 1 \\
Ahli Media 2 & 88 & 88 & 1 \\
Rata-rata & 88 & 88 & 1 \\
\hline
\end{tabular}


Hasil pengujian menunjukkan bahwa kedua validator menyatakan semua fitur yang berjumlah 88 dalam instrument penelitian berjalan dengan baik. Nilai Feature Completeness ditentukan dengan menggunakan persamaan:

$$
\begin{array}{ll}
X & =\mathrm{I} / \mathrm{P} \\
\mathrm{I} & =88 \\
\mathrm{P} & =88
\end{array}
$$

maka Feature Completeness bernilai 1. Pengujian karakteristik functionality dikatakan baik jika $X$ mendekati 1, sehingga dapat disimpulkan bahwa aplikasi yang dikembangkan berada pada kategori layak dan telah memenuhi aspek funcionality.

2) Aspek realiability

Pengujian realiability menggunakan aplikasi Webserver Stress Tool untuk melihat simulasi pengunjung website yang besar dan digunakan untuk pengujian tingkat stress pada suatu aplikasi web yang melewati media http/https pada waktu yang bersamaan. Jika sistem berhasil melewati pengujian ini tanpa gangguan berarti sistem dapat dinyatakan reliabel. Pada pengujian ini terdapat tiga pengujian yaitu click test, time test, dan ramp test.

a) Click test

Click Test digunakan untuk mensimulasikan pengklikan apa saja yang terdapat dalam halaman web tersebut yang selanjutnya setiap aksi pengklikan dihitung jeda waktu dan pengiriman yang dapat dilakukan oleh server dalam waktu bersamaan.

Tabel 2. Hasil click test per user

\begin{tabular}{cccccccc}
\hline $\begin{array}{c}\text { User } \\
\text { No. }\end{array}$ & Clicks & Hits & Errors & Avg. Click Time $[\mathrm{ms}]$ & Bytes & kbit/s & Cookies \\
\hline 1 & 1 & 1 & 0 & 5,291 & 4,935 & 7.46 & \\
2 & 1 & 1 & 0 & 5,189 & 4,935 & 7.61 & \\
3 & 1 & 1 & 0 & 5,187 & 4,935 & 7.61 & \\
4 & 1 & 1 & 0 & 5,185 & 4,935 & 7.62 & \\
5 & 1 & 1 & 0 & 4,741 & 4,935 & 8.33 & \\
6 & 1 & 1 & 0 & 4,532 & 4,935 & 8.71 & \\
7 & 1 & 1 & 0 & 3,702 & 4,935 & 10.66 & \\
8 & 1 & 1 & 0 & 3,048 & 4,935 & 12.95 & \\
9 & 1 & 1 & 0 & 2,020 & 4,935 & 19.54 & \\
10 & 1 & 1 & 0 & 1,815 & 4,935 & 21.76 & \\
\hline
\end{tabular}

Sumber: Pengujian reliability menggunakan Webserver Stress Tool 8, 2021

Berdasarkan Tabel 2, didapatkan hasil pengujian click test dengan jumlah virtual user 10 orang mengklik dengan jumlah klik yang sama tanpa terjadinya pesan error.

b) Time test

Time Test digunakan jumlah waktu yang digunakan pada pengujian. Hasil pengujian ditunjukkan pada Tabel 3. Berdasarkan Tabel 3 didapatkan hasil pengujian time test dengan jumlah virtual user 10 orang dengan jumlah klik rata-rata 6-7 kali klik dan menghasilkan rata-rata waktu yang berbeda-beda tanpa pesan error. 
Tabel 3. Hasil time test per user

\begin{tabular}{|c|c|c|c|c|c|c|c|}
\hline User No. & Clicks & Hits & Errors & Avg. Click Time [ms] & Bytes & kbit/s & Cookies \\
\hline 1 & 7 & 6 & 0 & 1,266 & 29,610 & 31.18 & \\
\hline 2 & 7 & 6 & 0 & 1,169 & 29,610 & 33.77 & \\
\hline 3 & 6 & 6 & 0 & 1,246 & 29,610 & 31.69 & \\
\hline 4 & 6 & 5 & 0 & 1,198 & 24,675 & 32.94 & \\
\hline 5 & 6 & 5 & 0 & 2,172 & 24,675 & 18.18 & \\
\hline 6 & 6 & 5 & 0 & 2,033 & 24,675 & 19.42 & \\
\hline 7 & 6 & 5 & 0 & 2,028 & 24,675 & 19.47 & \\
\hline 8 & 6 & 5 & 0 & 2,015 & 24,675 & 19.60 & \\
\hline 9 & 6 & 5 & 0 & 1,780 & 24,675 & 22.18 & \\
\hline 10 & 6 & 5 & 0 & 1,575 & 24,675 & 25.07 & \\
\hline
\end{tabular}

Sumber: Pengujian reliability menggunakan webserver stress tool 8, 2021

c) Ramp test

Ramp test digunakan untuk menghitung berapa banyak user yang dapat mengaksesnya sebelum terjadinya pesan error dengan memakai beberapa parameter uji yang terdiri dari virtual user yang mengakses secara simultan ke website uji dan periode waktu tertentu (satuan milisecond) yang akan menghasilkan nilai rata-rata waktu kecepatan respon web server dalam menampilkan (loading) halaman website yang diminta (requested) oleh user melalui web browser.

Tabel 4. Hasil ramp test per user

\begin{tabular}{|c|c|c|c|c|c|c|c|}
\hline User No. & Clicks & Hits & Errors & Avg. Click Time [ms] & Bytes & kbit/s & Cookies \\
\hline 1 & 6 & 5 & 0 & 1,900 & 24,675 & 20.78 & \\
\hline 2 & 6 & 5 & 0 & 2,427 & 24,675 & 16.27 & \\
\hline 3 & 5 & 4 & 0 & 2,395 & 19,740 & 16.49 & \\
\hline 4 & 5 & 4 & 0 & 2,901 & 19,740 & 13.61 & \\
\hline 5 & 4 & 4 & 0 & 1,900 & 19,740 & 20.78 & \\
\hline 6 & 4 & 3 & 0 & 3,396 & 14,805 & 11.63 & \\
\hline 7 & 3 & 2 & 0 & 2,997 & 9,870 & 13.18 & \\
\hline 8 & 3 & 2 & 0 & 4,229 & 9,870 & 9.34 & \\
\hline 9 & 2 & 1 & 0 & 3,966 & 4,935 & 9.96 & \\
\hline 10 & 2 & 1 & 0 & 5,988 & 4,935 & 6.59 & \\
\hline
\end{tabular}

Sumber: Pengujian reliability menggunakan webserver stress tool 8, 2021

Berdasarkan Tabel 4 didapatkan hasil pengujian ramp test dengan jumlah virtual user sebanyak 10 orang dimana virtual user tersebut mengakses dengan jumlah klik dan hasil rata-rata waktu yang didapatkan berbeda-beda dalam menampilkan (loading) halaman website tanpa terjadinya pesan error dimana user no. 1 dan 5 mendapatkan waktu tercepat load.

Berdasarkan hasil pengujian reliability dari ketiga jenis test dengan menggunakan click test, time test, dan ramp test maka dapat disimpulkan bahwa persentase kesuksesan dari pengujian sebesar 100\%, uraiannya dapat dilihat pada Tabel 5. 
Tabel 5. Hasil pengujian reliability

\begin{tabular}{lcc}
\hline Jenis Test & \multicolumn{1}{c}{ Persentase Error per test } & Persentase sukses per test \\
\hline Click Test & $0 \%$ & $100 \%$ \\
Time Test & $0 \%$ & $100 \%$ \\
Ramp Test & $0 \%$ & $100 \%$ \\
& Rata-rata & $100 \%$ \\
\hline
\end{tabular}

Sumber: Pengujian reliability menggunakan webserver stress tool, 2021

Berdasarkan Tabel 5, diperoleh rata-rata persentase sukses per test sebesar $100 \%$ hal ini berarti bahwa aplikasi yang dikembangkan memiliki reliabiliity tinggi.

3) Aspek portability

Pengujian portability dari aplikasi ini menggunakan bantuan dari web testing tool yakni browserstack.com dimana pengetesan dilakukan dengan cross browser testing atau pengecekan sistem dengan menggunakan berbagai browser pada desktop. Hasil pengujian portability dapat dilihat pada Gambar 18. Sehingga dapat dinyatakan bahwa media pada SIMAset layak untuk digunakan sebagai sistem informasi pengelolaan barang inventaris.

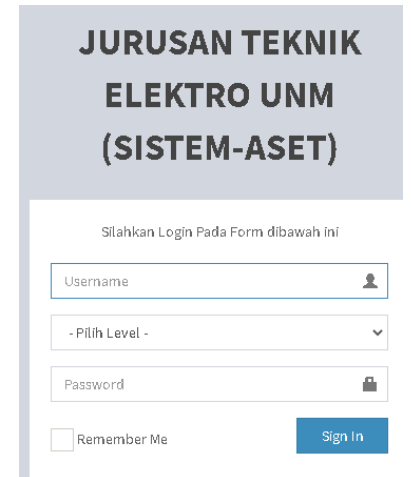

Gambar 18. Hasil Pengujian pada Windows 10 Chrome di BrowserStack

\section{KESIMPULAN}

Pengembangan aplikasi SIMAset dilakukan dengan menggunakan model pengembangan prototyping yang terdiri atas tujuh langkah yaitu analisis kebutuhan, membangun prototyping, evaluasi prototyping, pengkodean sistem, menguji sistem, evaluasi sistem dan menggunakan sistem. Aplikasi dikembangkan menggunakan Sublime Text dan PHP sebagai bahasa pemograman. Hasil pengembangan menghasilkan aplikasi SIMAset berbasis website yang dapat diakses setiap saat secara online. Kualitas sistem informasi inventaris berdasarkan standar kualitas perangkat lunak ISO 25010 layak untuk digunakan sebagai sistem informasi pengelolaan inventaris barang.

\section{DAFTAR PUSTAKA}

Agusvianto, H. (2017). Sistem informasi inventori gudang untuk mengontrol persediaan barang pada Gudang (Studi Kasus: PT. Alaisys Sidoarjo). JIEET (Journal of Information Engineering and Educational Technology), 1(1), 40-46.

Ariska, J., \& Jazman, M. (2016). Rancang bangun sistem informasi manajemen aset sekolah menggunakan teknik labelling QR code (Studi Kasus: MAN 2 Model Pekanbaru). Jurnal Ilmiah Rekayasa dan Manajemen Sistem Informasi, 2(2), 127-136.

Azhar, S. (2011). Building information modeling (BIM): Trends, benefits, risks, and challenges for the AEC industry. Leadership and Management in Engineering, 11(3), 241-252.

Heryanto, A., H. Fuad., \& D. Dananggi, D. (2014). Rancang bangun sistem informasi inventory barang berbasis web: Studi Kasus di PT. Infinetworks Global Jakarta. Jurnal Sisfotek Global, 4(2). 32-35. 
Hilbert, M. (2016). Big data for development: A review of promises and challenges. Development Policy Review, 34(1), 135-174.

Indrayani, E. (2011). Pengelolaan sistem informasi akademik perguruan tinggi berbasis teknologi informasi dan komunikasi (TIK). Jurnal Penelitian Pendidikan, 12(1), 51-67.

Jimmy, J. (2019). Perancangan perangkat lunak sistem informasi inventaris barang pada STMIK IBBI Medan. Jurnal Ilmiah Core IT: Community Research Information Technology, 7(1), 143-153.

Junglas, I., Abraham, C., \& Watson, R. T. (2008). Task-technology fit for mobile locatable information systems. Decision support systems, 45(4), 1046-1057.

Karim, N.A., A. Nawai., \& A.S.A.P. Salin. (2018). Inventory management effectiveness of a manufacturing company-Malaysian evidence. International Journal of Law and Management, 60(5), 1163-1178.

Lipursari, A. (2013). Peran sistem informasi manajemen (SIM) dalam pengambilan keputusan. Jurnal STIE Semarang (Edisi Elektronik), 5(1), 26-37.

Nugraha, G. A., Baidi, B., \& Bakri, S. (2021). Transformasi manajemen fasilitas pendidikan pada era disrupsi teknologi. Jurnal Ilmiah Ekonomi Islam, 7(2), 860-868.

Pranoto, A. O., \& Sediyono, E. (2021). Perancangan sistem informasi inventaris barang berbasis web. Jurnal Teknik Informatika dan Sistem Informasi, 7(2), 357-372.

Sari, A. O., \& Nuari, E. (2017). Rancang bangun sistem informasi persediaan barang berbasis web dengan metode fast (Framework for the applications). Jurnal PILAR Nusa Mandiri, 13(2), 261266.

Saryani, S., Harfizar, H., \& Maulana, J. F. (2019). Design of inventory data information systems in PT. Matahari Putra Prima. Tbk. Aptisi Transactions on Management (ATM), 3(2), 99-108.

Sholikhin, A., \& Riasti, B. K. (2013). Pembangunan sistem informasi inventarisasi sekolah pada Dinas Pendidikan Kabupaten Rembang berbasis web. IJNS-Indonesian Journal on Networking and Security, 2(2), 50-57.

Sidiq, A. H., \& Kurniawati, A. (2019). Analisis kebutuhan sistem administrasi bagian sidang ujian Universitas Gunadarma dengan metode pieces. Jurnal Ilmiah Teknologi dan Rekayasa, 24(1), 2234.

Werb, J., \& Lanzl, C. (1998). Designing a positioning system for finding things and people indoors. IEEE Spectrum, 35(9), 71-78. 